\title{
PERAN PERCEIVED VALUE MEMEDIASI HUBUNGAN KUALITAS PELAYANAN DENGAN KEPUASAN KONSUMEN
}

\author{
I Made Yoga Ananda Putra ${ }^{1}$ \\ Ketut Rahyuda ${ }^{2}$ \\ ${ }^{1,2}$ Fakultas Ekonomi dan Bisnis Universitas Udayana, Bali, Indonesia \\ email: anandayoga06@gmail.com
}

\begin{abstract}
ABSTRAK
Perkembangan restoran di Bali sebagai salah satu bagian dari industri pariwisata sangat pesat. Mulai dari berskala kecil sampai dengan restoran mewah. Demi bertahan diketatnya persaingan, pihak yang memasuki industri kuliner harus memiliki inovasi atau memberikan palayanan yang terbaik. Pemberian kualitas pelayanan yang baik akan berdampak pada kepuasan konsumen yang dimediasi oleh perceived value. Penelitian ini dilakukan untuk mengetahui peran perceived value memediasi hubungan kualitas dengan kepuasan konsumen (studi pada Semu Jaen Restaurant Ubud). Jumlah sampel yang diambil yaitu berjumlah 90 orang dengan metode non-probability sampling, khususnya purposive sampling. Pengumpulan data dilakukan dengan menyebar kuesioner. Teknik analisis data yang digunakan adalah patch analysis dan uji sobel. Hasil analisis menunjukkan bahwa kualitas pelayanan mempunyai pengaruh yang positif dan signifikan terhadap kepuasan konsumen, dan perceived value secara signifikan memediasi hubungan kualitas pelayanan dengan kepuasan konsumen.
\end{abstract}

Kata kunci: kualitas pelayanan, perceived value, dan kepuasan konsumen.

\begin{abstract}
The development of restaurants in Bali as one part of the tourism industry is very rapid. Started from the small scales to luxury restaurants. In order to survive the harsh competition, those who enter the culinary industry must have innovation or provide the best service. Providing a good service quality will have impact on customer satisfaction mediated by perceived value. This study was conducted to determine the role of perceived value that mediate the quality relationship with consumer satisfaction (studies at Semu Jaen Restaurant Ubud). The number of samples taken is 90 people with non-probability sampling method, especially purposive sampling. Data collection was done by spreading the questionnaire. Data analysis techniques used were patch analysis and test sobel. Based on this research, it is found that the service quality has positive and significant influence to customer satisfaction, and perceived value significantly mediates the relationship of service quality with the consumer satisfaction.
\end{abstract}

Keywords: quality of service, perceived value, and customer satisfaction. 
I Made Yoga Ananda Putra, Peran Perceived, ...

\section{PENDAHULUAN}

Pariwisata merupakan sektor ekonomi penting di Indonesia. Tahun 2009, pariwisata menempati urutan ketiga dalam hal penerimaan devisa setelah komoditi minyak dan gas bumi serta minyak kelapa sawit. Berdasarkan data tahun 2016, jumlah wisatawan mancanegara yang datang ke Indonesia sebesar 11.525.963 juta lebih atau tumbuh sebesar $10,79 \%$ dibandingkan tahun sebelumnya. Candi Prambanan dan Borobudur, Toraja, Yogyakarta, Minangkabau, dan Bali merupakan contoh tujuan wisata budaya di Indonesia (id.wikipedia.org). Hingga tahun 2012, terdapat 8 lokasi di Indonesia yang telah ditetapkan oleh UNESCO yang masuk dalam daftar Situs Warisan Dunia. Berdasarkan data dari Badan Pusat Statistik, sebelas provinsi yang paling sering dikunjungi oleh para turis adalah Bali sekitar lebih dari 4 juta disusul, DKI Jakarta, Daerah Istimewa Yogyakarta, Jawa Timur, Jawa Barat, Sumatera Utara, Lampung, Sulawesi Selatan, Sumatera Selatan, Banten dan Sumatera Barat. Sekitar 59\% turis berkunjung ke Indonesia untuk tujuan liburan, sementara 38\% untuk tujuan bisnis (Simanjuntak dkk., 2017:79).

Pulau Bali adalah tempat wisata terpopuler di Indonesia. Bali memiliki prospek dan potensi yang besar dalam Pariwisata Indonesia sehingga Pulau Bali dinobatkan sebagai pusat pariwisata di Indonesia bagian tengah. Badan Pusat Statistik (BPS) Bali mencatat kunjungan wisatawan mancanegara ke Bali sebesar 4,92 juta orang selama tahun 2016. Perkembangan restoran di Bali sebagai salah satu bagian dari industri pariwisatasangat pesat. Mulai dari berskala kecil sampai dengan restoran mewah.Industri kuliner memanjakan konsumen dengan beragam 
fasilitas di luar pangan sebagai kebutuhan pokok. Dwiwinarsih (2009), menyatakan demi bertahan diketatnya persaingan, pihak yang memasuki industri ini harus memiliki inovasi atau memberikan palayanan yang terbaik demi menarik konsumen atau mempertahankan konsumen. Brandine (2005), disisi lain keinginan konsumen sangat cepat berubah, karena adanya faktor-faktor penyebab antara lain kemajuan ilmu pengetahuan dan teknologi, pertumbuhan ekonomi, perkembangan kebudayaan, dan kebijakan pemerintah. Di luar faktor-faktor yang ditentukan, ternyata perkembangan kelangsungan industri kuliner sangat bergantung pada kemampuan wisata suatu daerah. Daerah yang memiliki potensi wisata menarik akan membawa dampak positif pada industri kuliner yang ada (Primananda dan Setiawan, 2014).

Perpaduan budaya serta wisata alam yang masih asri di Bali dapat di ditemukan di Kabupaten Gianyar terutama di daerah Ubud yang merupakan ciri dari wisata seni berbaur pemandangan alam yang indah. Kemampuan inilah yang menarik para pelaku di industri kuliner untuk meramaikan perekonomian setempat di samping tujuan utama mereka untuk menghasilkan laba. Keistimewaan Ubud dalam menarik sejumlah wisatawan datang menjadikan lahan bagi keberadaan wisata kuliner untuk bersaing menyenangkan hati konsumen dari berbagai inovasi yang ditawarkan. Berikutnya akan menampilkan data perkembangan restoran di Kabupaten Gianyar pada Tabel 1.

Berdasarkan data perkembangan restoran di Kabupaten Gianyar Tahun 2012-2016 menunjukkan jumlah restoran yang ada di Kabupaten Gianyar mengalami peningkatan setiap tahun. Dari Tahun 2012 jumlah restoran terus 
meningkat sampai Tahun 2015 dan pada Tahun 2015 jumlah restoran masih sama dengan jumlah restoran pada Tahun 2016, meskipun demikian dapat dikatakan pertumbuhan restoran yang ada memang menunjukkan bahwa industri kuliner di Kabupaten Gianyar saat ini mengalami pertumbuhan yang positif.

Tabel 1.

\begin{tabular}{cccc}
\multicolumn{5}{c}{ Data Perkembangan Restoran di Kabupaten Gianyar Tahun 2012-2016 } \\
\hline No & Tahun & $\begin{array}{c}\text { Jumlah Restoran } \\
\text { (Unit) }\end{array}$ & $\begin{array}{c}\text { Perubahan } \\
(\%)\end{array}$ \\
$\mathbf{1}$ & 2012 & 238 & - \\
$\mathbf{2}$ & 2013 & 378 & 0,59 \\
$\mathbf{3}$ & 2014 & 405 & 0,07 \\
$\mathbf{4}$ & 2015 & 504 & 0,24 \\
$\mathbf{5}$ & 2016 & 504 & 0 \\
\hline
\end{tabular}

Sumber: Dinas Pariwisata Provinsi Bali, 2017

Semu Jaen Restaurant merupakan salah satu restoran terletak di Jln. Bisma No. 3 Ubud, Gianyar, Bali. Semu Jaen Restaurant adalah restoran yang menyajikan menu masakan Internasional tetapi dengan taste dan spice yang lokal atau Balinese. Lokasinya tergolong strategis karena terletak di wilayah sentral Ubud seperti perkantoran, minimarket, cafe, bar dan dekat dengan objek wisata Monkey Forest. Keberadaan cafe dan bar yang ada di sekitar Semu Jaen Restaurant semakin meningkatkan persaingan. Assauri (2003: 25), persaingan yang semakin ketat menuntut sebuah perusahaan untuk selalu memanjakan pelanggan dengan memberikan pelayanan terbaik. Maka dari itu, Semu Jaen Restaurant harus meningkatkan kualitas pelayanan agar terciptanya kepuasan pengunjung. Selanjutnya akan menampilkan data jumlah konsumen dan penjualan Semu Jaen Restaurant Tahun 2016 dapat dilihat pada Tabel 2. 
Tabel 2.

Data Jumlah Konsumen dan Penjualan Semu Jaen Restaurant Tahun 2016

Bulan

Jumlah
Konsumen

(Orang)

$\begin{array}{ccc}\text { Januari } & 509 & - \\ \text { Februari } & 470 & (7,66 \%) \\ \text { Maret } & 395 & (15,96 \%) \\ \text { April } & 490 & 24,05 \% \\ \text { Mei } & 485 & (1,02 \%) \\ \text { Juni } & 622 & 28,25 \% \\ \text { Juli } & 1100 & 76,85 \% \\ \text { Agustus } & 1533 & 39,36 \% \\ \text { September } & 1136 & (25,90 \%) \\ \text { Oktober } & 1009 & (11,18 \%) \\ \text { November } & 658 & (34,79 \%) \\ \text { Desember } & 610 & (7,29 \%) \\ \text { Total } & \mathbf{8 7 2 2} & \end{array}$

Penjualan

(\%)

(Rp)

Rp98.891.181

Rp91.251.170

Rp76.529.657

Rp95.152.811

Rp94.163.538

Rp120.726.630

Rp213.387.542

Rp297.537.446

Rp220.603.165

Rp195.785.186

Rp127.635.812

Rp118.411.961

Rp1.750.076.099
Perubahan

$(\%)$

-
$(7,73 \%)$
$16,13 \%)$
$24,33 \%$
$(1,04 \%)$
$28,21 \%$
$76,75 \%$
$39,44 \%$
$(25,86 \%)$
$(11,25 \%)$
$(34,81 \%)$
$(7,23 \%)$

Sumber: Semu Jaen Restaurant, 2017

Tabel 2 Menunjukkan bahwa perkembangan jumlah konsumen dan penjualan Semu Jaen Restaurant dari Bulan Januari sampai dengan Bulan Desember Tahun 2016 berfluktuasi. Terjadinya fluktuasi selain karena ada banyaknya restoran, bar, dan cafe di sekitar Ubud, kurang lengkapnya fasilitas yang ditawarkan Semu Jaen Restaurant, karyawan kurang cepat dalam melayani tamu, karyawan dan staf kurang ramah dalam melayani pelanggan dimana sebabsebab tersebut kemungkinan merupakan faktor kualitas pelayanan Semu Jaen Restaurant.

Studi pendahuluan dilakukan berupa wawancara tidak terstruktur kepada owner dan 20 pengunjung di Semu Jaen Restaurant 11 dari 20 orang pengunjung mengalami ketidakpuasan atas pelayanan di Semu Jaen Restaurant. Salah satu keluhan yang dialami pengunjung Semu Jaen Restaurant yaitu makanan terlalu 
lama out, karyawan kurang tanggap terhadap keluhan yang disampaikan pelanggan, karyawan kurang mampu berkomunikasi dengan baik terhadap pengunjung. Karyawan kurang senyum dan greating serta toilet kurang nyaman. Melihat hal ini merupakan tantangan bagi perusahaan untuk perlu lebih memperhatikan kualitas pelayanan. Gonius (2013), menyatakan keluhan tidak dapat dihindari oleh perusahaan, terutama perusahaan yang bergerak dibidang jasa karena memberikan pelayanan yang terbaik tidaklah mudah. Mulyaningsih dan Suasana (2016), menyatakan pemberian kualitas pelayanan yang baik, akan menciptakan kepuasan bagi para pelanggannya. Maka dari itu penelitian ini dilakukan untuk mengetahui penilaian konsumen terhadap kualitas pelayanan ketika mengunjungi Semu Jaen Restaurant.

Dahulu kualitas pelayanan dikembangkan atas dasar kriteria yang ditetapkan oleh perusahaan. Sedangkan saat ini telah bergeser kepada pengertian sesusai dengan kriteria konsumen. Kualitas pelayanan didefinisikan sebagai seberapa jauh perbedaan antara kenyataan dan harapan pelanggan atas yang mereka terima. Kotler (dalam Ismail dan Josephat, 2012) jika kinerja dari kualitas pelayanan diberikan lebih rendah dari harapan maka konsumen akan merasa tidak puas, kinerja dari kualitas pelayanan yang diberikan sesusai harapan maka konsumen akan merasa puas, dan jika kinerja dari kualitas pelayanan yang diberikan sampai melebihi harapan, maka konsumen akan merasa sangat puas (delighted).Menurut Parasuraman et al. (1988), kualitas pelayanan jasa dapat dilihat dari lima dimensi antara lain: fasilitas fisik (tangibles), kehandalan (reliability), daya tanggap (responsiveness), jaminan (assurance) dan empati (emphaty). Jadi tingkat 
kepuasan konsumen terhadap pelayanan suatu perusahaan dapat dilihat dari kepuasan konsumen terhadap kelima dimensi pelayanan yang ditawarkan oleh perusahaan tersebut.

Mohammad dan Alhamadani (2011), perkembangan persaingan dan jumlah pesaing membuat perusahaan harus memperhatikan kebutuhan dan keinginan konsumen dan berusaha memenuhi harapan konsumen dengan cara memberikan pelayanan yang lebih baik dari pada yang dilakukan para pesaing. Menurut Utama (2003), mendefinisikan kualitas pelayanan sebagai perbandingan antara layanan yang diharapkan konsumen dengan layanan yang diterimanya. Cronin et al. (2000), menyatakan bahwa kualitas layanan memberikan suatu dorongan kepada pelanggan untuk menjalin ikatan hubungan yang kuat dengan perusahaan. Ikatan tersebut mendorong perusahaan untuk memahami dengan seksama harapan pelanggan serta kebutuhan mereka dalam jangka panjang. Layanan yang diberikan oleh suatu perusahaan apabila memenuhi kebutuhan pelanggan, menyebabkan kepuasan pelanggan yang lebih tinggi (Walker et al., 2006).

Pentingnya kepuasan pelanggan adalah hal yang berkaitan erat dengan kelangsungan perusahaan dan untuk pertumbuhan yang kuat di masa depan (Sheu and Mei, 2005). Kepuasan didefinisikan sebagai perasaan senang atau kecewa seseorang dari membandingkan produk yang dirasakan dalam hubungan dan harapanya (Kotler, 2009:139). Konsumen merasa puas dengan adanya jaminan kepuasan yang mereka terima benar dan dilakukan oleh sumber daya manusia yang berkompeten di bidangnya (Matovani, 2015). Sedangkan menurut Kotler dalam (Rosita, 2014), kepuasan merupakan fungsi dari kinerja yang dirasakan 
(perceived performance) dan harapan (expectations). Kepuasan pelanggan merupakan respon pelanggan terhadap ketidaksesuaian antara tingkat kepentingan sebelumnya dan kinerja aktual yang dirasakannya setelah pemakaian (Rangkuti, 2002:30).

Hillier et al. (2003), menyatakan variabel perceived value atau nilai yang dirasakan merupakan penilaian konsumen terhadap manfaat produk secara keseluruhan mengenai keuntungan yang diperoleh dari produk dan biaya untuk mendapatkan produk. Semakin tinggi perceived value konsumen, maka kepuasan konsumen semakin meningkat. Fornell (dalam Aryani, 2010) banyak manfaat yang diterima oleh perusahaan dengan tercapainya tingkat kepuasan pelanggan yang tinggi, yakni selain dapat meningkatkan loyalitas pelanggan juga dapat mencegah terjadinya perputaran pelanggan, mengurangi sensitivitas biaya operasional yang diakibatkan oleh meningkatnya jumlah pelanggan, meningkatkan efektivitas iklan, dan meningkatkan repustasi bisnis. Pemberian perceived value yang lebih tinggi pada pelayanan dan produk pada suatu perusahaan akan memberikan dampak yang penting di masa akan datang yang dapat memberikan keberhasilan perusahaan (Ryu et al., 2008).

Culiberg dan Rosjek (2010), menunjukkan kualitas pelayanan berpengaruh positif terhadap kepuasan konsumen hal ini berlawanan dengan penelitian dari Sanjuq (2014), menunjukkan bahwa kualitas pelayanan berpengaruh negatif terhadap kepuasan. Raza et al. (2012), serta beberapa hasil dari Manoj dan Sunil (2011), dan Razavi et al. (2012), menunjukkan bahwa kualitas pelayanan berpengaruh positif terhadap perceived value. Semu Jaen Restaurant perlu 
meningkatkan kualitas pelayanan agar perceived value untuk konsumen meningkat dan berdampak pada kepuasan konsumen. Kemampuan perusahaan untuk menggunakan reliability, responsiveness, asurance, empathy, dan tangibles dalam memberikan pelayanan akan meningkatkan perceived value atau nilai yang dirasakan konsumen akan semakin tinggi.

Beberapa penelitian terdahulu yang menjadi rujukan dalam penelitian ini menyatakan bahwa kualitas pelayanan berpengaruh positif dan signifikan terhadap perceived value. Penelitian yang dilakukan oleh Raza et al. (2012), menemukan bahwa kualitas pelayanan berhubungan positif dan signifikan terhadap perceived value dan kepuasan konsumen. Manoj dan Sunil (2011), menyatakan kemampuan perusahaan dalam memberikan kualitas produk atau pelayanan yang baik akan meningkatkan perceived value konsumen sehingga kepuasan konsumen semakin tinggi. Razavi et al. (2012), menyatakan pemberian kualitas pelayanan yang baik akan semakin meningkatkan perceived value konsumen. Hal yang serupa juga didukung oleh Chang dan Wang (2011) dan Abdelfattah et al. (2015). Berdasarkan hasil penelitian sebelumnya diatas maka dapat dibangun hipotesis sebagai berikut:

$\mathrm{H}_{1}$ : Kualitas Pelayanan Berpengaruh Positif Dan Signifikan Terhadap Perceived Value.

Mulyaningsih dan Suasana (2016), menyatakan pemberian kualitas pelayanan yang baik, akan menciptakan kepuasan bagi para pelanggannya. Kualitas pelayanan jasa dapat dilihat dari lima dimensi antara lain: fasilitas fisik 
(tangibles), kehandalan (reliability), ketanggapan (responsiveness), jaminan (assurance) dan empati (emphaty) (Parasuraman et al., 1988).

Hasil penelitian yang dilakukan Kurniawan (2012), menyatakan bahwa aspek fisik (tangibles) memiliki pengaruh positif terhadap kepuasan konsumen. Apabila pelayanan memiliki aspek fisik yang bagus, maka kepuasan konsumen akan semakin meningkat. Menurut Novita dan Nurcaya (2011), menyatakan dimensi kehandalan (reliability) berpengaruh positif dan signifikan terhadap kepuasan konsumen. Semakin baik persepsi pelanggan terhadap kehandalan (reliability), maka kepuasan konsumen akan semakin meningkat. Mahendra (2015), membuktikan dimensi daya tanggap (responsiveness) memiliki pengaruh positif terhadap kepuasan konsumen. Salim dan Subagio (2015) menyatakan dimensi jaminan (assurance) memiliki pengaruh positif dan signifikan terhadap kepuasan konsumen. Penelitian yang dilakukan oleh Culiberg dan Rosjek (2010) menyatakan dimensi empati (emphaty) memiliki pengaruh yang positif dan signifikan terhadap kepuasan konsumen. Berdasarkan hasil penelitian sebelumnya diatas maka dapat dibangun hipotesis sebagai berikut:

$\mathrm{H}_{2}$ : Kualitas Pelayanan Berpengaruh Positif Dan Signifikan Terhadap Kepuasan Konsumen.

Penelitian yang dilakukan oleh Ryu et al., (2008) pemberian perceived value yang lebih tinggi pada pelayanan dan produk pada suatu perusahaan akan memberikan dampak yang penting bagi keberhasilan perusahaan. Persepsi seorang pelanggan terhadap nilai atas kualitas yang ditawarkan relatif tinggi dari pesaing akan mampu memberikan pengaruh terhadap tingkat kepuasan pelanggan (Rifai 
dan Suryani, 2016). Perceived value merupakan variabel yang mempengaruh terhadap konsumen (Wulandari, 2015; Palitali, 2007; Siwantara 2011). Maka dari itu dirumuskan hipotesis sebagai berikut :

$\mathrm{H}_{3}$ : Perceived Value Berpengaruh Positif Dan Signifikan Terhadap Kepuasan Konsumen.

Hasil penelitian yang ditemukan oleh Howat dan Assaker (2013) menyatakan kualitas pelayanan menggerakkan perceived value konsumen. Perceived value diyakini sebagai pendorong kepuasan konsumen. Ketika konsumen menerima nilai yang besar dalam pelayanan, maka secara tidak langsung akan menghasilkan kepuasan konsumen. Net et al., (2009) dan Saif (2012), menyatakan variabel perceived value diidentifikasi sebagai variabel mediasi dan moderasi antara kualitas pelayanan dan kepuasan konsumen. Hal yang serupa juga didukung oleh Suaridewi dan Sulistyawati (2016) dan Hapsari et al., (2016). Berdasarkan hasil penelitian maka dapat dibangun hipotesis sebagai berikut:

$\mathrm{H}_{4}$ : Perceived Value Memediasi Kualitas Pelayanan Dengan Kepuasan Konsumen.

\section{METODE PENELITIAN}

Penelitian ini menggunakan desain penelitian asosiatif. Dikatakan demikian karena dalam penelitian ini menguji hubungan variabel kualitas pelayanan dengan kepuasan konsumen pada Semu Jaen Restaurant Ubud di Kabupaten Gianyar dimediasi oleh perceived value. 


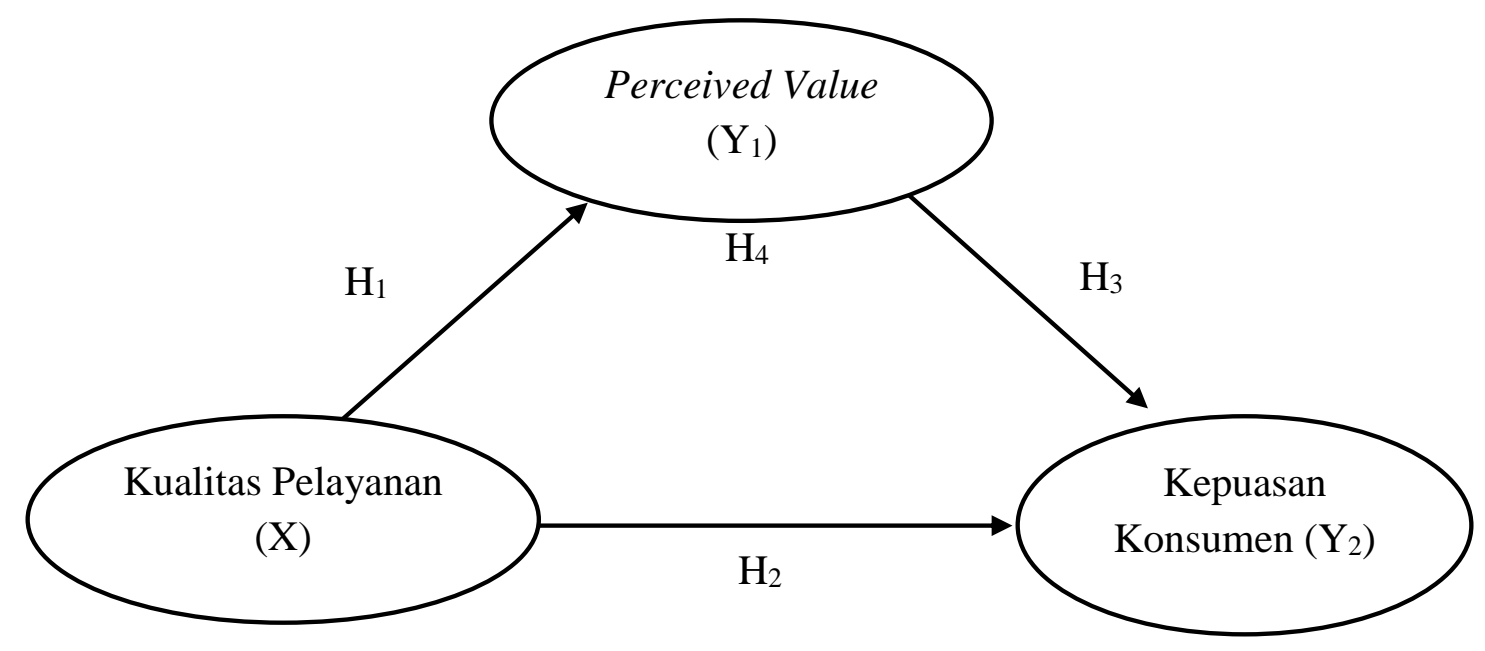

Gambar 1. Kerangka Konseptual

Sumber: Nek et al. (2009); Saif (2012); Hapsari et al. (2016)

Kualitas pelayanan didefinisikan sebagai upaya untuk memenuhi kebutuhan dan keinginan konsumen serta ketepatan dalam mengimbangi harapan konsumen. Adapun kualitas pelayanan dibagi menjadi beberapa dimensi yaitu kehandalan (reliability), daya tanggap (responsiveness), jaminan (assurance), rasa peduli (empathy), dan fasilitas fisik (tangibles).

Kehandalan (Reliability) adalah dimensi yang menunjukkan kemampuan Semua Jaen Restaurant memberikan pelayanan yang dijanjikan dengan segera, akurat dan memuaskan. Indikato empiris yang digunakan untuk menjelaskan dimensi kehandalan dalam Qin dan Prybutok (2009); Salim dan Subagio (2013); Naderian dan Baharun (2015) adalah, karyawan Semu Jaen Restaurant melayani konsumen dengan cepat $\left(\mathrm{X}_{1.1}\right)$; hidangan yang disajikan sesuai dengan pesanan $\left(\mathrm{X}_{1.2}\right)$; jam operasional Semu Jaen Restaurant sesuai dengan yang dikomunikasikan $\left(\mathrm{X}_{1.3}\right)$; proses pemesanan makanan yang cepat $\left(\mathrm{X}_{1.4}\right)$; daya Tanggap $\left(\mathrm{X}_{2}\right)$. 
Daya Tanggap (Responsiveness) merupakan keinginan atau ketersediaan karyawan untuk menanggapi kebutuhan atau keluhan konsumen. Indikator empiris yang digunakan untuk menjelaskan dimensi Daya Tanggap dalam Zhilin et al. (2004); Fowdar (2006); Qin dan Prybutok (2009) adalah, karyawan Semu Jaen Restaurant tanggap terhadap keluhan yang disampaikan oleh konsumen $\left(\mathrm{X}_{2.1}\right)$; karyawan Semu Jaen Restaurant bersedia untuk memberikan informasi $\left(\mathrm{X}_{2.2}\right)$; jaminan $\left(\mathrm{X}_{3}\right)$.

Jaminan (Assurance) adalah mencakup pengetahuan, keseponan atau keterampilan yang dimiliki karyawan yang dapat memberikan suatu kepercayaan kepada diri konsumen. Indikator yang dapat memberikan suatu kepercayaan kepada diri konsumen. Indikator empiris yang digunakan untuk menjelaskan dimensi jaminan dalam Qin dan Prybutok (2009); Istianto dan Tyra (2011); Salim dan Subagio (2013) adalah, karyawan Semu Jaen Restaurant sopan dan ramah dalam melayani konsumen $\left(\mathrm{X}_{3.1}\right)$; karyawan Semu Jaen Restaurant menjelaskan menu dengan baik dan jelas $\left(\mathrm{X}_{3.2}\right)$; rasa peduli $\left(\mathrm{X}_{4}\right)$.

Rasa Peduli (Empathy) adalah sikap kepedulian yang dilakukan karyawan dengan memberikan perhatian yang lebih kepada konsumen. Indikator empiris yang digunakan untuk menjelaskan dimensi Rasa Peduli dalam Fowdar (2006); Siddiqi (2011); Salim dan Subagio (2013) adalah, karyawan Semu Jaen Restaurantpaham dengan keinginan konsumen $\left(\mathrm{X}_{4.1}\right)$; karyawan Semu Jaen Restaurant tidak memandang status sosial dalam melayani konsumen $\left(\mathrm{X}_{4.2}\right)$; fasilitas Fisik $\left(\mathrm{X}_{5}\right)$. 
Fasilitas Fisik (Tangibles) merupakan segala sesuatu yang secara fisik bisa dilihat dan diamati secara langsung oleh konsumen pada Semua Jaen Restaurant. Indikator empiris yang digunakan untuk menjelaskan dimensi Fasilitas Fisik dalam Olorunniwo et al. (2006); Qin dan Prybutok (2009); Salim dan Subagio (2013) adalah, restoran bersih dan nyaman, karyawan berpenampilan dengan rapi, kebersihan toilet restoran terjaga, tempat parkir restoran memadai.

Perceived value merupakan perbedaan antara manfaat yang didapatkan oleh pelanggan dan biaya dikeluarkan oleh pelanggan dalam berkunjung ke restoran. Indikator empiris yang digunakan untukmengukur perceived value dalam penelitian Ryu et al. (2008); Qin dan Prybutok (2009); Morar (2013) sebagai berikut, Semu Jaen Restaurant bersih dan nyaman $\left(\mathrm{X}_{5.1}\right)$; karyawan Semu Jaen Restaurant berpenampilan dengan rapi $\left(\mathrm{X}_{5.2}\right)$; kebersihan toilet Semu Jaen Restaurant restoran terjaga $\left(\mathrm{X}_{5.3}\right)$; tempat parkir Semu Jaen Restaurant memadai untuk para pengunjung $\left(\mathrm{X}_{5.4}\right)$.

Kepuasan konsumen didefinisikan sebagai perasaan senang atau kecewa penumpang yang dihasilkan dari membandingkan kualitas pelayanan yang diberikan oleh restoran. Indikator empiris yang digunakan untuk menjelaskan variabel Kepuasan Konsumen menurut Olorunniwo et al. (2006); Qin dan Prybutok (2009); Angelova (2011), sebagai berikut, merasa puas dengan pengalaman makan di Semu Jaen Restaurant $\left(\mathrm{Y}_{2.1}\right)$; merasa senang dengan berkunjung ke Semu Jaen Restaurant $\left(\mathrm{Y}_{2.2}\right)$.

Populasi dalam penelitian ini adalah seluruh konsumen yang pernah bersantap di Semu Jaen Restaurant paling sedikit satu kali atau yang sedang 
berkunjung. Metode Penentuan sampel yang digunakan dalam penelitian ini yaitu non probability sampling. Teknik non probability sampling yang dipilih adalah purposive sampling. Metode pengumpulan data dalam penelitian ini adalah dengan metode survey dengan teknik wawancara menggunakan kuesioner. Kemudian, butir - butir pernyataan diukur dengan skala Likert.

\section{HASIL DAN PEMBAHASAN}

Responden dalam penelitian ini berjumlah 90 orang yang merupakan pengunjung Semu Jaen Restaurant. Karakteristik responden ini ditinjau dari beberapa variabel demografi yang digambarkan melalui jenis kelamin, usia, pendidikan terakhir, frekuensi berkunjung dan disajikan dalam Tabel 3.

Tabel 3.

Karakteristik Responden Semu Jaen Restaurant Tahun 2017

\begin{tabular}{|c|c|c|c|c|}
\hline No. & Kriteria & Klasifikasi & $\begin{array}{l}\text { Jumlah } \\
\text { (Orang) }\end{array}$ & Persentase \\
\hline \multirow[t]{3}{*}{1.} & Jenis Kelamin & Laki-laki & 23 & $25,6 \%$ \\
\hline & & Perempuan & 67 & $74,4 \%$ \\
\hline & Jumlah & & 90 & $100 \%$ \\
\hline \multirow[t]{4}{*}{2.} & Usia & 17-24 tahun & 24 & $26,7 \%$ \\
\hline & & 25-35 tahun & 52 & $57,8 \%$ \\
\hline & & $>35$ tahun & 14 & $15,6 \%$ \\
\hline & Jumlah & & 90 & $100 \%$ \\
\hline \multirow[t]{3}{*}{3.} & Pendidikan Terakhir & SMA & 27 & $30 \%$ \\
\hline & & Perguruan Tinggi & 63 & $70 \%$ \\
\hline & Jumlah & & 90 & $100 \%$ \\
\hline \multirow[t]{5}{*}{4} & Frekuensi Berkunjung & Pertama kali & 62 & $68,9 \%$ \\
\hline & & Dua kali & 0 & $0 \%$ \\
\hline & & Tiga kali & 0 & $0 \%$ \\
\hline & & Lebih dari tiga kali & 28 & $31,1 \%$ \\
\hline & Jumlah & & 90 & $100 \%$ \\
\hline
\end{tabular}

Sumber : Data primer diolah, 2017

Berdasarkan Tabel 3 menjelaskan responden penelitian didominasi oleh kaum perempuan yaitu sejumlah 74,4 persen dan sisanya reponden laki-laki yang berjumlah 25,6 persen dari total jumlah responden. Hasil ini menunjukkan bahwa 
kaum perempuan cenderung lebih sering mengunjungi Semu Jaen Restaurant dibandingkan laki-laki.

Ditinjau dari kriteria usia, mayoritas responden berusia antara 25-35 tahun dan jumlah 57,8 persen total jumlah responden. Hasi ini menunjukkan masyarakat yang berusia 25-35 tahun memiliki ketertarikan yang lebih besar untuk mengunjungi Semu Jaen Restaurant. Salah satu fasilitas yang dapat dimanfaatkan di Semu Jaen Restaurant yaitu tersedianya wi-fi serta suasananya yang membuat nyaman untuk berkumpul.

Dilihat dari kriteria pendidikan terakhir, responden dengan tingkat perguruan tinggi berjumlah 70 persen dari jumlah keseluruhan responden. Responden yang berstatus sebagai mahasiswa memiliki angka tertinggi yaitu sebesar 30 persen dari jumlah seluruh responden. Hal ini menunjukkan pengunjung dari Semu Jaen Restaurant didominasi oleh masyarakat yang sudah lulus dari perguruan tinggi.

Tabel 4.

Hasil Uji Validitas

\begin{tabular}{ccccc}
\hline Variabel & Dimensi & Instrumen & Koefisien Korelasi & Keterangan \\
Kualitas & Reliability $\left(\mathrm{X}_{1}\right)$ & $\mathrm{X}_{1.1}$ & 0,782 & Valid \\
Pelayanan & & $\mathrm{X}_{1.2}$ & 0,618 & Valid \\
$(\mathrm{X})$ & & $\mathrm{X}_{1.3}$ & 0,685 & Valid \\
& & $\mathrm{X}_{1.4}$ & 0,799 & Valid \\
& & $\mathrm{X}_{2.1}$ & 0,939 & Valid \\
& Responsiveness & $\mathrm{X}_{2.2}$ & 0,925 & Valid \\
& $\left(\mathrm{X}_{2}\right)$ & 0,686 & Valid \\
& Assurance $\left(\mathrm{X}_{3}\right)$ & $\mathrm{X}_{3.1}$ & 0,917 & Valid \\
& & $\mathrm{X}_{3.2}$ & 0,899 & Valid \\
& Empathy $\left(\mathrm{X}_{4}\right)$ & $\mathrm{X}_{4.1}$ & 0,880 & Valid \\
& Tangible $\left(\mathrm{X}_{5}\right)$ & $\mathrm{X}_{4.2}$ & 0,533 & Valid \\
& $\mathrm{X}_{5.1}$ & 0,772 & Valid \\
& $\mathrm{X}_{5.2}$ & 0,781 & Valid \\
& $\mathrm{X}_{5.3}$ & 0,823 & Valid \\
& $\mathrm{X}_{5.4}$ & 0,958 & Valid \\
\hline
\end{tabular}


E-Jurnal Manajemen Unud, Vol. 7, No. 5, 2018: 2793-2822

\begin{tabular}{llll}
\hline & $\mathrm{Y}_{1.2}$ & 0,971 & Valid \\
Kepuasan Konsumen $\left(\mathrm{Y}_{2}\right)$ & $\mathrm{Y}_{2.1}$ & 0,926 & Valid \\
& $\mathrm{Y}_{2.2}$ & 0,843 & Valid \\
\hline
\end{tabular}

Sumber : data diolah, 2017

Tabel 4 menunjukkan bahwa instrumen-instrumen pada setiap variabel dalam penelitian ini sudah lebih besar dari 0,3 . Hal ini dapat dilihat dari nilai koefisien validitas yang lebih besar dari 0,3 yang diujikan secara bertahap per 30 responden dari total 90 responden. Maka dari itu, instrumen-instrumen pada setiap variabel adalah valid dan dapat digunakan untuk melakukan penelitian atau menguji hipotesis penelitian.

Tabel 5.

Hasil Uji Reliabilitas

\begin{tabular}{cccc}
\hline Variabel & Dimensi & Cronbach's & Keterangan \\
& & Alpha & \\
Kualitas & Kehandalan (Reliability) & 0,815 & Reliabel \\
$\begin{array}{c}\text { Pelayanan } \\
\text { (X) }\end{array}$ & Daya Tanggap & 0,949 & Reliabel \\
& (Responsiveness) & & \\
& Jaminan (Asurance) & 0,815 & Reliabel \\
& Empati (Emphaty) & 0,912 & Reliabel \\
& Keberwujudan (Tangibles) & 0,794 & Reliabel \\
\multicolumn{2}{c}{ Perceived Value $\left(\mathbf{Y}_{1}\right)$} & 0,972 & Reliabel \\
Kepuasan Konsumen (Y) & 0,901 & Reliabel \\
\hline
\end{tabular}

Sumber : data diolah, 2017

Variabel dapat dikatakan reliabel jika nilai Cronbach Alpha >0,6. Tabel 5 menyajikan hasil uji reliabilitas instrumen penelitian. Tiga instrumen penelitian yaitu variabel kualitas pelayanan, perceived value dan kepuasan konsumen memiliki koefisien cronbach's alpha yang lebih besar dari 0,60 sehingga pernyataan kuesioner tersebut reliable.

Pengujian data penelitian ini menggunakan teknik jalur (Path Analysis). Tahapan dalam melakukan teknik analisis jalur yaitu pertama, merancang model analisis jalur secara teoritis ditunjukkan pada gambar 2 berikut: 


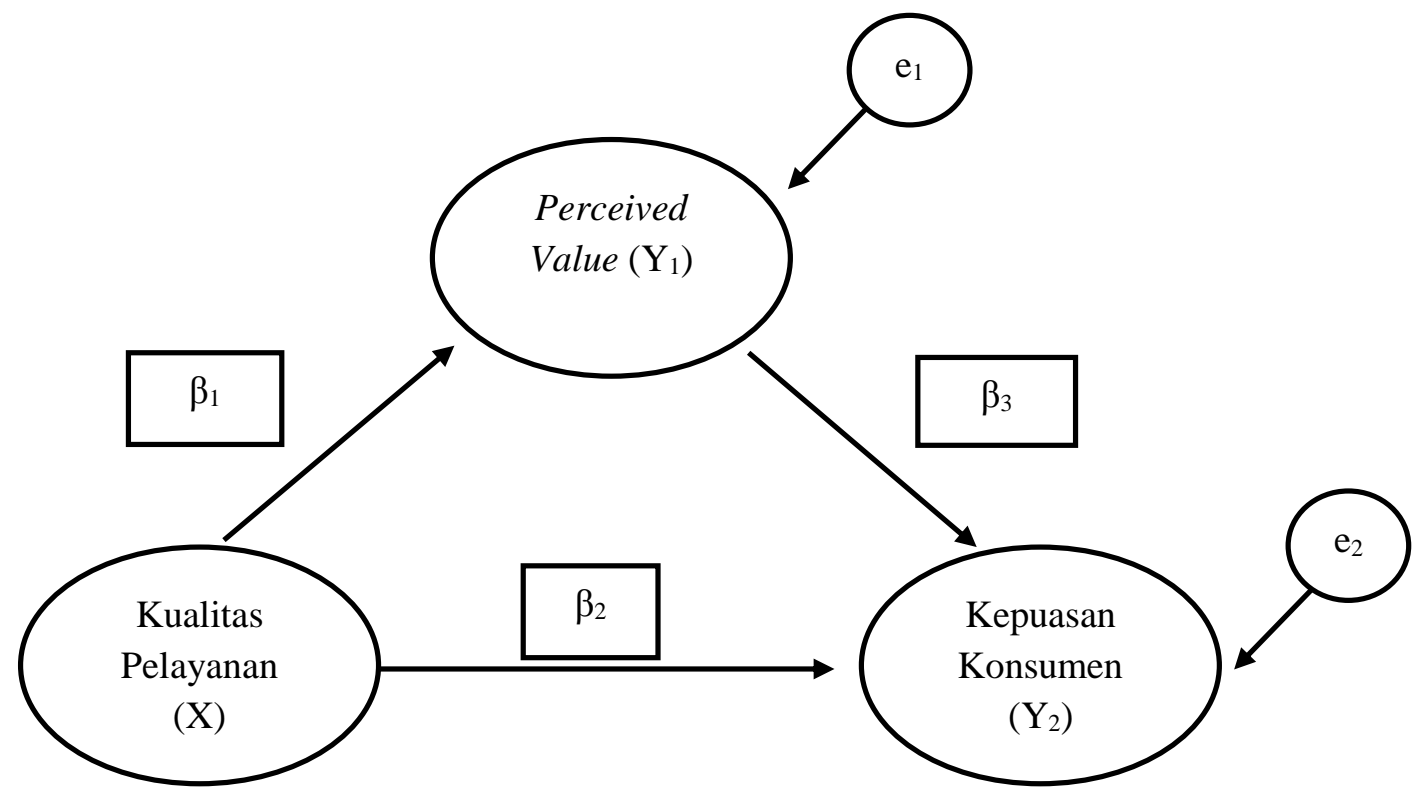

Gambar 2. Model Analisis Jalur Peran Perceived Value Memediasi Hubungan Kualitas Pelayanan Dengan Kepuasan Konsumen

Sumber : data diolah, 2017

Kedua perhitungan koefisien path dilakukan dengan analisis regresi ditunjukkan pada Tabel 6 .

Tabel 6.

Hasil Analisis Regresi Linier Berganda Struktur 1

\begin{tabular}{|c|c|c|c|c|c|c|}
\hline \multirow{2}{*}{\multicolumn{2}{|c|}{ Model }} & \multicolumn{2}{|c|}{$\begin{array}{c}\text { Unstandardized } \\
\text { Coefficients }\end{array}$} & \multirow{2}{*}{$\begin{array}{c}\text { Standardized } \\
\text { Coefficients } \\
\text { Beta }\end{array}$} & \multirow[t]{2}{*}{$\mathrm{t}$} & \multirow[t]{2}{*}{ Sig. } \\
\hline & & $\mathrm{B}$ & Std. Error & & & \\
\hline \multirow[t]{2}{*}{1} & (Constant) & 1.008 & .498 & & 2.026 & .046 \\
\hline & Kualitas Pelayanan & .762 & .108 & .601 & 7.062 & .000 \\
\hline \multicolumn{4}{|c|}{ R Square } & & & 0,362 \\
\hline \multicolumn{4}{|c|}{ Adjusted R Square } & & & 0,354 \\
\hline \multicolumn{4}{|c|}{ F Statistik } & & & 49,873 \\
\hline \multicolumn{4}{|c|}{ Signifikansi } & & & $\mathbf{0 , 0 0 0}$ \\
\hline
\end{tabular}

Sumber : data diolah 2017

Berdasarkan hasil analisis jalur substruktur 1 seperti yang disajikan pada

Tabel 6, maka persamaan strukturalnya adalah sebagai berikut :

$$
\begin{aligned}
& \mathrm{Y}_{1}=\alpha+\beta_{1} \mathrm{X}+\mathrm{e} \\
& \mathrm{Y}_{1}=1,008+0,601 \mathrm{X}+\mathrm{e}
\end{aligned}
$$


Tabel 7.

Hasil Analisis Regresi Linier Berganda Struktur 2

\begin{tabular}{|c|c|c|c|c|c|c|}
\hline \multirow{2}{*}{\multicolumn{2}{|c|}{ Model }} & \multicolumn{2}{|c|}{$\begin{array}{c}\text { Unstandardized } \\
\text { Coefficients }\end{array}$} & \multirow{2}{*}{$\begin{array}{c}\text { Standardized } \\
\text { Coefficients } \\
\text { Beta }\end{array}$} & \multirow[t]{2}{*}{$\mathrm{t}$} & \multirow[t]{2}{*}{ Sig. } \\
\hline & & B & Std. Error & & & \\
\hline \multirow[t]{3}{*}{1} & (Constant) & .782 & .383 & & 2.045 & .044 \\
\hline & Kualitas Pelayanan & .438 & .102 & .385 & 4.315 & .000 \\
\hline & Perceived Value & .405 & 080 & .450 & 5.048 & .000 \\
\hline \multicolumn{4}{|c|}{ R Square } & & & 0,559 \\
\hline \multicolumn{4}{|c|}{ Adjusted R Square } & & & 0,549 \\
\hline \multicolumn{4}{|c|}{ F Statistik } & & & 55,070 \\
\hline \multicolumn{4}{|c|}{ Signifikansi } & & & 0,000 \\
\hline
\end{tabular}

Berdasar hasil analisis jalur substrukrutal 2 seperti yang disajikan pada

Tabel 7, maka persamaan strukturalnya adalah sebagai berikut :

$\mathrm{Y}_{2}=\alpha+\beta_{1} \mathrm{X}+\beta_{3} \mathrm{Y}_{1}+\mathrm{e}$

$\mathrm{Y}_{2}=0,782+0,385 \mathrm{X}+0,450 \mathrm{Y}_{1}+\mathrm{e}$

Berdasarkan model substruktur 1 dan substruktur 2, maka dapat disusun model diagram jalur akhir. Sebelum menyusun model diagram jalur akhir, terlebih dahulu dihitung standar error sebagai berikut :

$$
\begin{aligned}
& \mathrm{Pe}_{\mathrm{i}}=\sqrt{1-\mathrm{R}_{\mathrm{i}}^{2}} \\
& \mathrm{Pe}_{1}=\sqrt{1-{R_{1}}^{2}}=\sqrt{1-0,362}=0,798 \\
& \mathrm{Pe}_{2}=\sqrt{1-R_{2}^{2}}=\sqrt{1-0,559}=0,661
\end{aligned}
$$

Berdasarkan perhitungan pengaruh error $\left(\mathrm{Pe}_{1}\right)$ didapatkan hasil pengaruh error $\left(\mathrm{Pe}_{1}\right)$ sebesar 0,798 dan pengaruh error $\left(\mathrm{Pe}_{2}\right)$ sebesar 0,661. Hasil koefisien determinasi total adalah sebagai berikut :

$$
\begin{aligned}
\mathrm{R}^{2}{ }_{\mathrm{m}} & =1-\left(\mathrm{Pe}_{1}\right)^{2}\left(\mathrm{Pe}_{2}\right)^{2} \\
& =1-(0,798)^{2}(0,661)^{2} \\
& =1-(0,636)(0,437)
\end{aligned}
$$


$=1-0,278=0,722$

Nilai determinasi total sebesar 0,722 mempunyai arti bahwa sebesar 72,2\% persen variasi kepuasan konsumen dipengaruhi oleh variabel Kualitas Pelayanan dan Perceived Value, sedangkan sisanya sebesar sebesar 28,2 \% dijelaskan oleh faktor lain yang tidak dimasukkan ke dalam model.

Hasil koefisien jalur pada hipotesis penelitian dapat digambarkan pada Gambar 3 berikut :

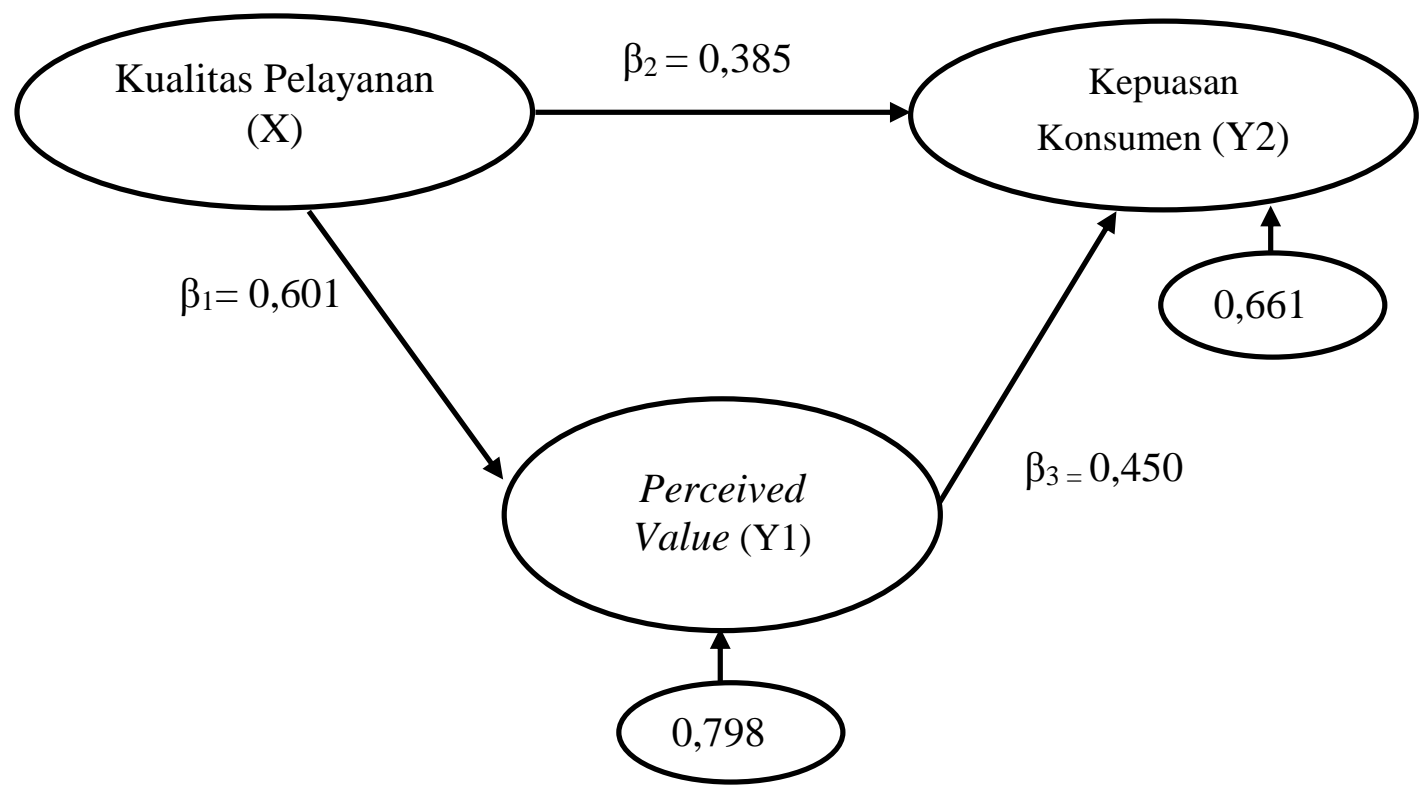

\section{Gambar 3. Validasi Model Diagram Jalur Akhir}

Sumber : data diolah, 2017

Berdasarkan gambar 3 validasi model diagram jalur akhir, maka dapat dihitung besarnya pengaruh langsung dan tidak langsung serta pengaruh total antar variabel. 
Tabel 8.

Pengaruh Langsung dan Pengaruh Tidak Langsung serta Pengaruh Total Kualitas Pelayanan ( $\left.\mathbf{X}_{1}\right)$, Perceived Value $\left(\mathbf{Y}_{1}\right)$, dan Kepuasan Konsumen ( $\left.\mathbf{Y}_{2}\right)$

\begin{tabular}{|c|c|c|c|c|}
\hline Pengaruh & Pengaruh & Pengaruh & Langsung & Pengaruh Total \\
\hline Variabel & Lasngsung & $\begin{array}{l}\text { Melalui Perceived } \\
\left(\beta_{1} \times \beta_{3}\right)\end{array}$ & Value (Y1) & \\
\hline $\mathbf{X}_{1} \rightarrow \mathbf{Y}_{1}$ & 0,601 & (1) & & 0,601 \\
\hline $\mathbf{X}_{1} \rightarrow \mathbf{Y}_{2}$ & 0,385 & 0,270 & & 0,655 \\
\hline $\mathbf{Y}_{1} \rightarrow \mathbf{Y}_{2}$ & 0,450 & - & & 0,450 \\
\hline
\end{tabular}

Uji Sobel merupakan alat analisis untuk menguji signifikansi dari hubungan tidak langsung antara variabel independen dengan variabel dependen yang dimediasi oleh variabel mediator. Bila nilai kalkulasi $\mathrm{Z}$ lebih besar dari 1,96 (dengan tingkat kepercayaan 95 persen), maka variabel mediator dinilai secara signifikan memediasi hubungan antara variabel terikat dan variabel bebas.

Tabel 9.

Hasil Uji Sobel

\begin{tabular}{cc}
\hline Nilai $\mathbf{Z}$ & Sig \\
3,912 & 0,000 \\
\hline Sumber : Data primer diolah (2017).
\end{tabular}

Sumber : Data primer diolah (2017).

Berdasarkan hasil Uji Sobel pada Tabel 10 menunjukkan bahwa hasil tabulasi $\mathrm{Z}=3,912>1,96$ dengan tingkat signifikansi $0,000<0,05$ yang berarti variabel mediator yakni perceived value dinilai secara signifikansi memediasi hubungan antara kualitas pelayanan terhadap kepuasan konsumen.

\section{Pengaruh Kualitas Pelayanan Terhadap Perceived Value}

Penelitian ini memiliki beberapa tujuan salah satunya yaitu untuk mengetahui pengaruh kualitas pelayanan terhadap perceived value. Secara keseluruhan deskripsi jawaban responden meliputi dimensi kualitas pelayanan yang terdiri dari responsivense, assurance, reliability, emphaty, dan tangibles mengindikasi bahwa secara keseluruhan kualitas pelayanan yang diberikan Semu 
Jaen Restaurant telah dilakukan dengan baik dan maksimal. Hasil pengujian menunjukkan bahwa nilai koefisien beta positif sebesar 0,601 dengan tingkat signifikansi sebesar 0,000 (kurang dari 0,05 ) yang artinya $\mathrm{H}_{1}$ diterima. Hal ini menunjukkan bahwa variabel kualitas pelayanan berpengaruh secara positif dan signifikan terhadap perceived value.

Hasil penelitian ini menunjukkan bahwa semakin baik kualitas pelayanan yang diberikan akan berdampak pada semakin meningkatnya perceived value yang dirasakan konsumen. Hasil penelitian ini sesuai dengan pernyataan yang diungkapkan oleh Caruana et al. (2000) beserta Varki dan Colgate (2001). Sureshchandar et al. (2002) menyatakan, kemampuan perusahaan untuk memeberikan kualitas pelayanan yang baik akan semakin meningkatkan perceived value konsumen.

\section{Pengaruh Kualitas Pelayanan Terhadap Kepuasan Konsumen}

Penelitian ini memiliki beberapa tujuan salah satunya yaitu untuk mengetahui pengaruh kualitas pelayanan terhadap kepuasan konsumen. Hasil pengujian menunjukkan bahwa nilai koefisien beta positif sebesar 0,450 dengan

tingkat signifikansi sebesar 0,000 (kurang dari 0,05) yang berarti $\mathrm{H}_{2}$ diterima. Hal ini menunjukkan kualitas pelayanan berpengaruh terhadap kepuasan konsumen. Hasil penelitian ini menunjukkan semakin baik kualitas pelayanan yang diberikan Semu Jaen Restaurant yang diberikan maka kepuasan konsumen akan semakin meningkat. Hal sebaliknya apabila pemberian kualitas pelayanan yang tidak baik makan konsumen tidak merasa puas. 
Hasil penelitian ini didukung oleh Novita dan Nurcahya (2011); Atika et al. (2013); Atmawati dan Wahyudin (2007), Afrizawati (2012) menyatakan, kekuatan kualitas pelayanan merupakan basis kepuasan konsumen, karena dari kualitas pelayanan akan memunculkan kepuasan tersendiri yang dirasakan oleh konsumen yang mempergunakan pelayanan baik dalam bentuk jasa maupun produk.

\section{Pengaruh Perceived Value Terhadap Kepuasan Konsumen}

Berdasarkan hasil pengujian pada hipotesis, ditemukan pengaruh positif dan signifikan pada variabel perceived value terhadap kepuasan konsumen, dengan koefisien beta sebesar 0,385 dengan tingkat signifikansi 0,000 (kurang dari 0,05) yang artinya $\mathrm{H}_{3}$ diterima, dan mengindikasikan bahwa perceived value berpengaruh positif dan signifikan terhadap kepuasan konsumen. Hasil ini didukung oleh penelitian yang dilakukan oleh Lai et al. (2009); Fiol et al. (2009); Roig et al. (2009). Petric (2004) menyatakan perceived value merupakan salah satu variabel penting yang mempengaruhi kepuasan konsumen. Woodruff (1997) menyatakan perceived value merefleksikan persepi kognitif konsumen terhadap kepuasan nilai yang dirasakan oleh konsumen. Maka dari itu, pemberian perceived value yang semakin baik akan berdampak pada kepuasan konsumen.

\section{Perceived Value Memediasi Hubungan Kualitas Pelayanan Dengan Kepuasan}

\section{Konsumen}

Berdasarkan hasil pengujian pada variabel mediasi didapatkan hasil bahwa variabel perceived value memiliki nilai kalkulasi Z lebih besar dari 1,96 (dengan tingkat kepercayaan 95 persen). Nilai Z sebesar 3,912 dimana nilai ini lebih besar 
dari nilai yang ditentukan yaitu 1,96 yang artinya $\mathrm{H}_{4}$ diterima. Hal ini menunjukkan bahwa bahwa perceived value mampu memediasi secara signifikan hubungan antara kualitas pelayanan dengan kepuasan konsumen. Maka dari itu, perceived value memiliki pengaruh tidak langsung antara kualitas pelayanan terhadap kepuasan konsumen. Hasil penelitian ini sesuai dengan penelitian sebelumnya oleh Chang et al. (2009) serta Erggert dan Ulaga (2002).

\section{SIMPULAN DAN SARAN}

Berdasarkan hasil analisis penelitian dan hasil pembahasan yang telah dilakukan, maka dapat ditarik beberapa kesimpulan yaitu, kualitas pelayanan berpengaruh positif dan signifikan terhadap perceived value. Hasil penelitian menunjukkan pemberian pelayanan yang baik kepada konsumen akan mempengaruhi perceived value yang semakin tinggi. Kualitas pelayanan berpengaruh positif dan signifikan terhadap kepuasan konsumen. Pernyataan ini menunjukkan semakin baik pelayanan yang diberikan karyawan Semu Jaen Restaurant akan semakin meningkatkan kepuasan konsumen.

Perceived value berpengaruh positif dan signifikan terhadap kepuasan konsumen, yang menunjukkan pemberian perceived value yang baik kepada konsumen akan semakin meningkatkan kepuasan konsumen Semu Jaen Restaurant. Perceived value secara signifikan mampu memediasi hubungan kualitas pelayanan dengan kepusan konsumen. Pernyataan ini menunjukkan variabel perceived value mempengaruhi kepuasan konsumen secara tidak langsung. Pemberian kualitas pelayanan yang baik akan berdampak pada 
perceived value konsumen yang semakin tinggi. Semakin tinggi perceived value yang dirasakan maka akan berdampak pada kepuasan konsumen.

Berdasarkan hasil analisis penelitian, hasil pembahasan, dan kesimpulan, maka saran yang dapat diberikan yaitu bagi perushaan, penelitian ini hendaknya menjadi bahan pertimbangan bagi Semu Jaen Restaurant untuk selalu meningkatkan pelayanan sehingga tercapainya kepuasan konsumen. Apabila konsumen merasa puas terhadap pelayanan yang diberikan maka akan berdampak pada loyalitas konsumen. Perceived value juga menjadi variabel yang patut ditingkatkan dengan cara menyajikan hidangan yang sesuai dengan biaya yang dikeluarkan oleh konsumen. Saran yang dapat diberikan kepada Semu Jaen Restaurant yaitu dengan terus meningkatkan kualitas pelayanan dan perceived value konsumen. Pemberian inovasi dan kreasi yang baru pada suasana seperti furniture yang baru maupun menu hidangan yang baru di Semu Jaen Restaurant merupakan beberapa cara yang dapat diterapkan untuk meningkatkan kepuasan konsumen.

\section{REFERENSI}

Abdelfattah, Fadi Abdelmuniem. Muhammad Sabbir Rahman. Mohamad Osman. 2015. Assessing the Antecedents of Customer Loyalty on Healthcare Insurance Products: Service Quality; Perceived Value Embedded Model. Journal of Industrial Engineering and Management, 8(5): 1639-1660.

Afrizawati. 2012. Analisis Pengaruh Kualitas Pelayanan Terhadap Kepuasan Pelanggan Pada Hotel Arista Palembang. Jurnal Orasi Bisnis, VII:ISSN: 2085-1375.

Angelova, Biljana. Zekiri Yusuf. 2011. Measuring Customer Satisfaction with Service Quality Using American Customer Satisfaction Model (ACSI Model). International Journal of Academic Research in Business and Social Sciences, 1(3): 232-258. 
Atika Paramitha, Rahyuda, Suasana. 2013. Pengaruh Kualitas Pelayanan Terhadap Kepuasan dan Loyalitas Pelanggan Garuda Indonesia di Denpasar. Jurnal Fakultas Ekonomi Universitas Udayanan,7(1): 9-28.

Atmawati, Rustika dan Wahyuddin, M. 2004. Analisis Pengaruh Kualitas Pelayanan Terhadap Kepuasan Konsumen Pada Matahari Departement Store di Solo Grand Mall. Jurnal Ekonomi Manajemen Sumber Daya, 5(1): 54-61.

Assauri. 2003. Manajemen Pemasaran Jasa. Jilid 1. Jakarta: PT Gramedia.

Badan Pusat Statistik Bali. 2016. Provinsi Bali dalam Angka Tahun 2016. Denpasar.

Chang Hsin Hsin, Wang Hsin-Wei. 2011. The Moderating Effect Of Customer Perceived Value on Online Shopping Behavior. Online Information Review, 35(3): 333-359.

Chang, Hsin Hsin, Yaoe-Hua Wang, and Wen-Yin Yang. 2009. The Impact od EService Quality, Custemer Satisfaction and Loyalty on E-Marketing: Moderating Effect of Perceived Value. Total Quality Management 20(4): 423-443.

Caruana, A., Money, A.H. Berthon P.R. 2000. Service Quality and Satisfaction The Moderating Role Of Value. European Journal of Marketing, 34(11): 1338-1352.

Cronin, J. Joseph Jr, Michael K. Brady, G. Tomas M. Hult. 2000. Assessing the Effects of Quality, Value, and Customer Satisfaction on Consumer Behavioral Intentions in Service Environments. Journal of Retailing, 76(2): 193-218.

Culiberg, B. Rojsek, I. 2010. Identifying Service Quality Dimension as Antecedents to Customer Satisfaction in Retail Banking. Economic and Business Review, 12 (03): 151-166.

Dinas Pariwisata Provinsi Bali. 2016. Data Direktori 2016. Denpasar.

Dwiwinarsih. 2009. Analisis Tingkat Kepuasan Konsumen Terhadap Pelayanan Bakmi Aisy Di Depok. Jurnal Ekonomi Manajemen, 5(1): 31-57.

Fiol, L., Alcaniz, E., Tena, M., Garcia, J. 2009, Customer Loyalty in Clusters: Perceived Value and Satisfaction as Antecedents, Journal of Business-toBusiness Marketing, 16(3): 276-316.

Fowdar, Rooma Roshnee Ramsaran. 2006. Developing a Service Quality Questionnaire For The Hotel Industry in Mauritius. Journal of Vacation Marketing, 13(1): 19-27. 
Gonius, Natalia. 2013. Studi Deskriptif Tentang Costumer Complaints di Restoran Wok Noodles di Galaxy Mall Surabaya. Jurnal Ilmiah Mahasiswa Universitas Surabaya, 2(1): 1-15.

Griselda, Gretel dan Panjaitan, Tagor Muda. 2007. Analisis Pengaruh Kualitas Layanan Terhadap Kepuasan Konsumen Restoran Pulau Dua. DeRaMa Jurnal Manajemen, 2(1): 39-63.

Hapsari, Raditha, Michael Clemes, David Dean. 2016. The Mediating Role of Perceived Value on the Relationship between Service Quality and Customer Satisfaction: Evidence from Indonesian Airline Passengers. Procedia Economics and Finance Journal, 3(5): 388-395.

Howat, G., Assaker, G. 2013. The Hierarchical Effects of Perceived Quality on Perceived Value, Satisfaction, and Loyalty: Empirical Results From Public, Outdoor Aquatic Centres in Australia. Sport Management Review, Elsevier Journal, 16(3): 268-284.

Istianto dan Tyra to, John Hendra dan Maria Josepshine Tyra. Analisis Pengaruh Kualitas Layanan Terhadap Kepuasan Pelanggan Rumah Makan Ketty Resto. Jurnal Ekononomi Dan Informasi Akuntansi, 1(3): 275-293.

Kotler, Philip, dan Kevin Lane Keller, 2009. Manajemen Pemasaran. Edisi 13. Jilid 1. Jakarta: Penerbit Erlangga.

Kotler, Philip, dan Kevin Lane Keller, 2009. Manajemen Pemasaran. Edisi 13. Jilid 2. Jakarta: Penerbit Erlangga.

Kurniawan, Adi. 2012. Pengaruh Kualitas Pelayanan Terhadap Kepuasan Pelanggan Pos Express Di Pt. Pos Indonesia (Persero) Kantor Pos Cukir. Jurnal Pendidikan Ekonomi, 1(1): 2-16.

Lai F, Griffin M, Babin B J, 2009. How Quality, Value, Image and Stisfaction Create Loyalty at A Chinese Telecom. Journal of Business Research,6(2): 980-986.

Mahendra, Komang Gede. 2015. Pengaruh Kualitas Layanan Terhadap Kepuasan Konsumen Pada Hotel Griya Sunset Kuta. E-Jurnal Manajemen, 4(2): 488299.

Manoj, Edward. Sunil, Sahadev. 2011. Role Of Switching Costs In The Service Quality, Perceived Value, Customer Satisfaction and Customer Retention Linkage. Asia Pacific Journal of Marketing and Logistics, 23(3): 327-345.

Matovani, Erwina. 2015. Kualitas Pelayanan Kantor Kesyahbandaran Dan Otoritas Pelabuhan Kelas Ii Kijang Terhadap Agen Pelayaran Swasta. Jurnal Repositori UMRAH. 
Mohammad, Anbeer Abraheem And Alhamadani, Shireen Yaseen Mohammad. 2011. Service Quality Perspective and Costumer Satisfaction in Commercial Bank Working in Jordan. Middle EasternFinance dan Economics, 1(4): 6172.

Morar, Doriana Dumitrela. 2013. An Overview Of The Consumer Value Literature - Perceived Value, Desired Value. International Conference Marketing - from information to decision, 6(1): 169-186.

Mulyaningsih, Luh Ayu. I. G. A. K. G. Suasana. 2016. Pengaruh Kualitas Layanan dan Citra Perusahaan Terhadap Kepuasan Nasabah Pada BANK OCBC NISP. E-Jurnal Manajemen, 5(1): 1-30.

Naderian, Anahita. Rohaizat Baharun. 2015. Service Quality and Consumer Satisfaction and Loyalty association Moderated by Switching Cost in Hospitality Industry. International Journal of Hospitality \& Tourism Systems, 8(1): 11 - 22

Nek Kamal Yeop Yunus, Azman Ismail, Zubrina Ranee Juga, Salomawati Ishak. 2009. Service Quality Dimensions, Perceive Value and Customer Satisfaction: Abc Relationship Model Testing. IBEJ Journal, 2(1): 66-78.

Novita, Indri. Nurcaya. 2011. Pengaruh Dimensi Kualitas Pelayanan Jasa Terhadap Kepuasan Pelanggan D\&I Skin Centre Denpasar. E-Jurnal Manajemen, 2(8): 918-937.

Olorunniwo, Festus. Maxwell K. Hsu. 2006. A Typology Analysis of Service Quality, Customer Satisfaction and Behavioral Intentions in Mass Services. Managing Service Quality, 16(2): 106-123.

Palitali, Alida. 2007. Pengaruh Nilai Pelanggan, Kepuasan Terhadap LoyalitasNasabah Tabungan Perbankan di Sulawesi Selatan. Jurnal Manajemen dan Kewirausahaan, 9(1): 73 - 81 .

Parasuraman, Zeithaml, dan Berry. 1988. SERVQUAL: A Multiple-Item Scale for Measuring Consumer Perception of Service Quality. Journal of Retailing. Marketing Science Institute, 1(64): 12-40.

Qin, H., Prybutok, V. R. 2009. Service Quality, Customer Satisfaction, And Behavioral Intentions In Fast-Food Restaurants. International Journal of Quality and Service Sciences, 1(1): 78-95.

Raza Muhammad, Ahmad Nabel Sidiqquei, Hayat M.Awan, Khurram Bukhari. 2012. Relationship Between Service Quality, Perceived Value, Satisfaction And Revisit Intention in Hotel Industry. Interdisclipinary Journal of Contemporary Research in Business, 4(8): 788-805. 
Razavi, S.M. Safari, H, Shafie, H. 2012. Relationships Among Service Quality, Customer Satisfaction and Customer Perceived Value: Evidence From Iran's Software Industry. Journal of Management and Strategy, 3(3): 28-37.

Rifai, Ahmad. Suryani, Alit. 2016. Peran Customer Perceived Value Pada Kepuasan Pelanggan Tiket Online. E-Jurnal Manajemen, 5(6): 3305-3334.

Roig JCF, Garcia JS, Tena 2009. Perceived Value and Customer Loyalty in Financial Service. Service Industries Journal, (29): 775-789.

Rosita, Ade. 2014. Pengaruh Kualitas Pelayanan Terhadap Tingkat Kepuasan Masyarakat Pada Rumah Sakit Umum Daerah Badung. Citizen Charter UNUD, 1(2).

Ryu, Kisang. Han, Heesup. Kim, Tae-Hee. 2008. The Relationships Among Overall Quick-Casual Restaurant Image, Perceived Value, Customer Satisfaction and Behavioral Intentions. International Journal of Hospitality Management, 27(3): 459-469.

Saif, Ulah Malik. 2012. Customer Satisfaction, Perceived Service Quality and Mediating Role od Perceived Value. International Journal of Marketing Studies, 4(1): 68-76.

Salim, Winy. Subagio, Hartono. 2013. Analisa Pengaruh Service Quality Terhadap Costumer Satisfaction Rempah Restaurant. Jurnal Manajemen Pemasaran Petra, 1(2): 1-9.

Sanjuq, Ghalib. 20014. The Impact of Service Quality Delivery on Customer Satisfaction in theBanking Sector in Riyadh, Saudi Arabia. International Journal of Business Administration,5(4): 77-84.

Sheu, Mei. 2005. Service Quality and Customer Satisfaction Antecedents Of Customer's Re-Patronage Intentions. European Journal of Marketing, 36 (8): 811-828.

Siddiqi, Kazi Omar. 2011. Interrelations between Service Quality Attributes, CustomerSatisfaction and Customer Loyalty in theRetail Banking Sector in Bangladesh. International Journal of Business and Management, 6(3): 1833-3850

Simanjuntak, Bungaran Antonius Tanjung. Flores Nasution. Rosramadhana. 2017. Sejarah Pariwisata: Menuju Perkembangan Pariwisata Indonesia. Jakarta: Yayasan Pustaka Obor Indonesia.

Siwantara, I Wayan. 2011. Pengaruh Nilai Pelanggan Terhadap Kepuasan dan Loyalitas Pelanggan Serta Kinerja Costumer Relationship Management (Studi Pada Halo Corporate PT. Telkomsel Bali). Jurnal Bisnis dan Kewirausahaan, 7(3): 150-161. 
Suariedewi, Mas. Eka Sulistyawati. 2016. Peran Perceived Value Memediasi Pengaruh Kualitas Pelayanan Terhadap Kepuasan Konsumen. E-Jurnal Manajemen, 5(12): 8199-8226.

Sureshchandar, G.S., Rajendran, C \& Anantharaman, R.N. 2002. The Relationship Between Service Quality and Customer Satisfaction - A Factor Specific Approach. Journal of Service Marketing, 16(4): 363-379.

Utama, Agung. 2003. Analisis Pengaruh Persepsi Kualitas Pelayanan Terhadap Kepuasan Pelanggan Rumah Sakit Umum Cakra Husada Klaten. Journal Universitas Negeri Yogyakarta, 1(2): 96 - 110.

Varki, S, Colgate, M. 2001. The Role of Price Perception in An Intergrated Model of Behavioural Intentions. Journal Of Service Research, 3(3): 232-40.

Walker, R. H., Johnson, L.W, Leonard, S. 2006. Rethinking The Conceptualization Of Customer Value And Service Quality Within The Service-Profit Chain. Emerald Journal, 16(1): 23-36.

Woodruff, R.B. 1997. Customer Value: The Next Souerce of Competitive Advantage. Journal of the Academy of Marketing Science, 25(2): 139-153.

Wulandari, Agustini. 2015. Pengaruh Kualitas Pelayanan Terhadap Kepuasan Pasien dengan Perceived Value Sebagai Variabel Mediasi Pada Rsud Dr.Moewardi di Surakarta. Jurnal Ekonomi dan Kewirausahaan, 15(1): 1927.

Zhilin Yang. Minjoon Jun. Robin T. Peterson. 2004. Measuring Customer Perceivedonline Service QualityScale Development and Managerial Implications. International Journal of Operations \&Production Management, 24(1): 1149-1174. 